\title{
Identification of Common EFL Errors in Writings of Kosovar Freshmen
}

\author{
Sermin Turtulla \\ Ass. Prof. Dr., Faculty of Philology \\ Elsev Brina Lopar
}

Ass. Prof. Dr., Faculty of Education, University of Prizren "Ukshin Hoti”

\begin{abstract}
This descriptive study aims to identify the most common English language errors committed by EFL freshmen of the second largest university in Kosova. Data was collected from a corpus of hand-written essays from 210 freshmen in English Language and Literature Department at University of Prizren during the winter semester of 2016/2017 academic year. Data was analyzed using frequency count and percentage distribution. Findings of the study revealed that faulty use of prepositions and present simple tense made up almost half of the total number of errors committed.
\end{abstract}

Keywords: EFL errors, linguistic errors, EFL teaching

\section{Introduction}

Identification of learners' errors in English language learning is not a new topic, but one that was studied at length by numerous researchers since 1960's (Corder, 1967; Richards, 1970; Corder, 1981; Dulay, Burt, \& Krashen, 1982; Taylor, 1986; Ellis, 1989). Language errors are seen as valuable information not only for researchers seeking information on how second language is acquired, but also for teachers looking into how to improve their language teaching, and students probing on which language areas they need to strengthen (Corder, 1967; Corder, 1981; Dulay, Burt, \& Krashen, 1982). Consequently, the wave of error research has spread fast to other countries trying to identify and analyze specific errors committed by learners learning English as a foreign or a second language (Royster, 1913; Earhart \& Small, 1915; Politzer \& Ramirez, 1973; Lu, 2010; Nezami \& Najafi, 2012; Novita, 2014; Prvulović, 2014; Kotsyuk, 2015). However, there is scarce research into errors committed by Albanians (Kaçani, 2013) or Kosovars who learn English as a foreign language (Gërmizaj, 2005) and hardly any specific statistical research. The present study aims to bridge this gap by identifying the most common linguistic errors that Kosovar learners tend to make in written English, without inquiring into what "causes of the deviation might be" (Dulay, Burt, \& Krashen, 1982, p.139). In addition, it hopes to provide specific data that can be used to improve teaching practices in the short term and raise the awareness of all the parties involved in the learning process in the long term.

\section{Error definitions}

The relevant literature reveals a number of error definitions. Dulay, Burt, and Krashen (1982) defined errors as deviations from the Standard English, while James (1998) defined them as faulty language uses that do not match language that native speakers would use. In addition, researchers have tried to clarify the distinction between errors and mistakes in terms of learners' language abilities. Thus, if students make linguistic faults and can self-correct without external assistance this is considered a mistake and as such they show unsystematic errors in performance; in contrast, if students make language faults but cannot self-correct without additional studying this is considered an error and as such they make systematic errors in competence (Corder, 1967; James, 1998). Sometimes performance errors appeare as a result of carelessness or fatigue, whereas competence errors are always a sign of learners' insufficient knowledge of language rules (Dulay, Burt, \& Krashen, 1982). Subsequent studies in second language acquisition influenced how errors were viewed by linguists and researchers and showed that learner errors shouldn't be overlooked and ignored, but valued as factual indicators of an ongoing learning process (Corder, 1967). 


\section{Error causes and classification}

Consequently, the importance given to errors has propelled research alongside two routes: explaining causes and classifying taxonomies. Beginning 1960s, causes of errors have been analyzed and explained using different theories of which contrastive analysis and error analysis are the most prominent (Dulay, Burt, \& Krashen, 1982). The former emphasized the influence of the mother tongue in second language acquisition, wherein the interference of first language is seen as impeding the learning process and not assisting it (Dulay, Burt, \& Krashen, 1982). The latter emerged as a reaction to error causes that could not be explained by contrastive approach, and in turn included the aspect of the learner's own idiosyncratic language which is used during the process of learning itself (Corder, 1981; Dulay, Burt, \& Krashen, 1982).

In the second route of research, language theoreticians have restlessly tried to cover and explain all the errors committed by learners of different backgrounds (Dulay, Burt, \& Krashen, 1982). This route generated the four principal error taxonomies: 1. Linguistic category classified errors alongside the language segments where the errors occurred including phonology, syntax, morphology, lexicon, and discourse components; 2. Surface strategy identified errors based on cognitive processes that learners use to alter the new language namely omitting, adding, misforming, or misordering parts of language; 3 . Comparative taxonomy compared second language error structures between second language learners and first language learners and aligned errors in two groups: developmental and interlingual, and 4. Communicative effect taxonomy classified errors based on their effect on communication grouping them into global and local errors (Dulay, Burt, \& Krashen, 1982). Similarly, Richards (1970) explains error occurrence on developmental basis which he further groups under four groups: 1. over-generalization where learners merge two grammar structures into one faulty structure, for example, the third person singular ending and irregular past forms of verbs; 2 . ignorance of rule restrictions where learners are ignorant of exceptions to rules or limitations to general rules with examples of errors of preposition and article use; 3 . incomplete application of rules which include incorrect use of question forms and statement forms, and 4. false concepts hypothesized which includes the "occurrence of structures whose deviancy represents the degree of development of the rules required to produce acceptable utterances" (p.12) which covers incorrect use of question forms.

However, defining and classifying errors properly showed to be an arduous activity. For instance, some errors which are affected by the differences between first and second languages systems are also found in languages that have similar grammar structures such as the case of verb inflection in English, Albanian and Spanish (Corder, 1967; Dulay, Burt, \& Krashen, 1982). Furthermore, some errors tend to fall into both over-generalization and ignorance of rule restrictions, while others cannot be precisely grouped under certain categories such as intralingual or developmental (Richards, 1970; Dulay, Burt, \& Krashen, 1982). These observed difficulties in describing errors and classifying their causes show that knowing only the differences in learners' first language and second language learning systems might not be enough for errorless acquisition (Corder, 1967), nor might one single theory account for all possible errors that come out of the learning process (Dulay, Burt, \& Krashen, 1982).

\section{Error significance}

Identifying errors is especially significant in teaching. Results from these studies create a strong foundation for making improvements in teaching, showing gaps in student knowledge that need to be worked on further, and creating a favorable environment for successful acquisition (Corder, 1967). In addition, studies show that language learners make use of conscious and subconscious processes in language learning. These practices affect the quality of learning because they "filter" what new information can enter the mind, then organize and monitor the overall classroom instruction (Dulay, Burt, \& Krashen, 1982, p.45). The conscious and subconscious processes have more significance in adult learning than it was previously thought; in fact, research shows that adults make use of inner processes when communicating in a foreign language more than they rely on conscious use of grammar rules in speech (Dulay, Burt, \& Krashen, 1982). It is this "linguistic ignorance" of errors that shows how students handle gaps in their knowledge to come with a solution in their language use (James, 1998) and are in control of their own learning process governed also by other factors including personal needs and desires (Ellis, 1989).

\section{Errors across nations}

Research shows that errors are widespread and attributed not only to non-natives but also native speakers of English Language. Far from being exhaustive, we are enlisting only a few samples to give a simple outline of errors committed across nations. The most frequently mentioned five error types are verb tenses, subject-verb agreement, prepositions, 
articles and singular/plural forms of nouns. While natives struggle with errors in subject-verb agreement and adjectiveadverb use (Royster, 1913; Earhart \& Small, 1915), foreign language learners, as reported by Poulisse in 1997 (as cited in James, 1998), keep on making the error in the third person singular (s) ending, which is one of the most difficult errors to overcome (Dulay, Burt, \& Krashen, 1982); subject-verb agreement is a common error among Filipino learners (Gustilo \& Magno, 2012); Ukrainian university student's essays are marked by errors in article use, wrong use of verb forms, incorrect use of singular/plural nouns, possessive's, and errors in use of modifiers and quantifiers (Kotsyuk, 2015); Indonesian freshmen at Andalas University struggle with similar errors in their written essays with the five most frequent ones in verb tenses, subject-verb agreement, article, and prepositions (Novita, 2014); the most common error types in Pakistani learners are verb tenses mainly past and present (Zafar, 2016); Iranian learners struggle with articles, verb forms, singular/plural, prepositions, and tenses (Nezami \& Najafi,2012); Albanians make a range of errors in articles and plural forms (Kaçani, 2013); bilingual and monolingual Mexican school children make errors in simple past tense and prepositions (Politzer \& Ramirez, 1973); Serbian students have difficulties with determiners, especially articles and pronouns (Prvulović, 2014); Malaysian secondary school children have their share of errors with the five most frequent in singular/plural form, verb tense, word choice, prepositions and subject-verb agreement (Darus, \& Subramaniam, 2009), and Turkish learners make errors in preposition use (Tunaz, Muyan, \& Muratoğlu, 2016).

\section{Methods}

In this study, data was collected from a total of 210 written essays from EFL Kosovar freshmen of Department of English Language and Literature at Prizren University in the academic year 2016/2017. The students were asked to write a oneparagraph essay on the topic of student motivation causes within a time-length of 60 minutes as part of their composition course evaluation process. Additionally, they were explicitly asked to avoid grammar and writing mistakes so that the aspect of performance errors is eliminated (Richards, 1970; Dulay, Burt, \& Krashen, 1982). The collected errors are contextualized and semantically related because they are written about a particular topic within a given situation and not just random sentences which would make identification difficult (Corder, 1967).

The methodology in this study followed the same complementary procedures used by other researchers including description, categorization, and descriptive statistics (Politzer \& Ramirez, 1973). Within the framework of descriptive taxonomy, data was classified using the linguistic category scheme with an added focus on morphological component (Dulay, Burt, \& Krashen, 1982). This scheme prevailed over the other taxonomies because of three reasons: 1. they are an easy reference to both teachers and students, 2. most of textbooks and lessons are developed based on linguistic features of language although in recent years this has been bolstered by context (Dulay, Burt, \& Krashen, 1982), so teachers can adapt them easily into their classroom teaching, and 3 . in order to avoid challenges that other scholars have faced in attempts to define categories (Politzer \& Ramirez, 1973; Dulay, Burt, \& Krashen, 1982). Accordingly, errors identified in this study adhere to basic morphological structures (noun, verb, adj...) because of their convenience and userfriendly format, while resort to syntactic terms (subject-verb agreement, modifier...) only when the former is inappropriate.

Data was identified and coded using the comprehensive first and second cycle coding method (Saldana, 2009) focusing only on mostly grammar-based errors including erroneous capitalization and the empty subject (it), and not on acceptability, correctness, strangeness, or infelicity of errors themselves (James, 1998). Errors were extracted from participant's writings as were put on paper, without taking into consideration writer's intentions of what they wanted to write (Taylor, 1986). Therefore, the process of error identification included several considerations:

The participants' first choice of words determined correction of the rest of the sentence, for example "..our family spend money.." was classified under incorrect use of present simple tense affirmative third person (our family spends money, rather than our families spend money), "if a student feel good", "we don't have anyone to ask....so we failed sometimes" which was grouped with incorrect present simple negative form rather than incorrect past use, "why people don't learning" was aligned under present simple affirmative and not present continuous tense, or "may will happen yet" was grouped under modals instead of future will. However, when the first word was insufficient to determine the category, meaning of the first part of the sentence was considered as a guiding point such as "I remember my dad always says to me...", or "that's what happening to me lately". Finally, when neither of the two was helpful, the arbitrary decision (Dulay, Burt, \& Krashen, 1982) based on logic and reason was followed, for example "after they are getting graduated ....won't stay" was placed under present tense rather than present continuous. 
Although erroneous sentences were chopped for convenience purposes, researchers gave a careful consideration to chopping process by focusing on the overall meaning of respective sentences/text such as "students leave the city ...and going to another one", "..better to work ...than going at..".

Participants' personal choice of words and sentence structure was given priority over the researchers, experts' choice of sentence construction, or choice of other linguistics forms, so the researcher focused on "observable [rather than inferred] characteristics" of errors (Dulay, Burt, \& Krashen, 1982, p. 146). In this view, we have not included sentences that used a personal choice of words and sentence structure such as "and thinking the fact that they have..." , "as a quote say..", "they are going to have mistakes", "the fault goes to someone else's", "students that are interested to study", "choose a place that they don't belong there", "we can do our future better", "they're poor and they should work instead of study", "they think that could not find ...", ", to have lack of knowledge, it's a disaster", "they less their motivation", "we are lack of motivation", "to start tell students,", "start stopping this", and "became who they wanted to be".

sentences with ambiguous meaning were not included such as "we cannot find our jobs in a near future", "the reason why is this problem going far is the internet", "in the future".

Once errors were identified and selected, an additional $\operatorname{coder}^{1}$ was asked to code in order to address the validity of the coding process whereby the undecided sentences were disregarded from the research data set. In the first cycle, a preliminary linguistic code was assigned to 19 items, then continued into the second cycle in order to further manage and filter the data so that more manageable categories are formed (Saldana, 2009) and it was decided on the final seven. Finally, descriptive statistics was performed on coded structures for frequency counts of incorrect uses and percentage distribution using Excel.

\section{Results}

From the total of 210 student-produced papers, 148 (70.5\%) papers contained errors and $62(29.5 \%)$ did not. Total number of errors identified is 406 . The highest number of errors was seen in prepositions (21\%), and the lowest was recorded in wrong use of present simple questions and past simple negative structure (0\%) with only 2 errors, respectively (Figure 3 .). The most frequent errors registered were wrong use of prepositions and present simple tense structures, which comprised almost half of all registered errors, 171 (42\%) (Figure 1,2.).

Within the category of prepositions, the highest number of errors was registered in wrong use of to $20 \%$ and the lowest, while $1 \%$. Similarly, learners made use of the five most frequent prepositions including to, for, in, on, $\varnothing$ (no need for a preposition) which covered the total of $70 \%$ of all prepositions (Figure 4.).

Figure 1. Aggregated categories of errors

\begin{tabular}{lll} 
Aggregated category & Sum of ttl & Sum of $\%$ \\
Prepositions & 87 & $21 \%$ \\
Present simple & 84 & $21 \%$ \\
Singular/Plural & 68 & $17 \%$ \\
Other tenses & 60 & $15 \%$ \\
Others & 52 & $13 \%$ \\
It empty subject & 35 & $9 \%$ \\
Article & 20 & $5 \%$ \\
\hline Grand Total & 406 & $100 \%$ \\
\hline
\end{tabular}

${ }^{1}$ Prof. Agim Mullafetahu is a senior EFL teacher with a vast experience in teaching. 
Figure 2. Percentages of aggregated errors

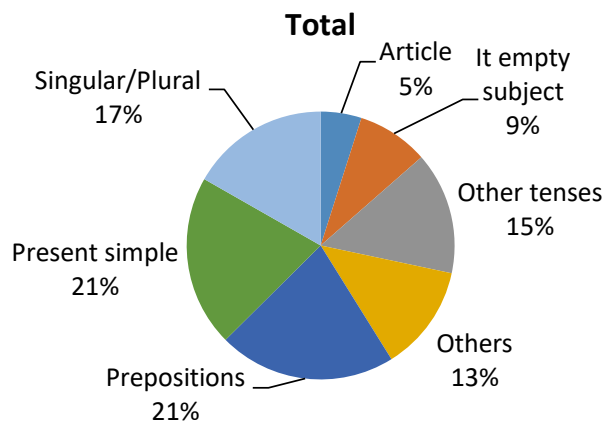

Figure 3. Total of identified error categories

\begin{tabular}{|c|c|c|}
\hline Error category &.+ Sum of TtI & Sum of $\%$ \\
\hline Prepositions & 87 & $21 \%$ \\
\hline Singular/Plural & 68 & $17 \%$ \\
\hline Present simple & 66 & $16 \%$ \\
\hline It empty subject & 35 & $9 \%$ \\
\hline Articles & 20 & $5 \%$ \\
\hline Adjective/Adverb & 18 & $4 \%$ \\
\hline Present simple negative & 16 & $4 \%$ \\
\hline Capital letters & 14 & $3 \%$ \\
\hline Modals & 12 & $3 \%$ \\
\hline Infinitive & 10 & $2 \%$ \\
\hline Pronouns & 10 & $2 \%$ \\
\hline Present perfect & 10 & $2 \%$ \\
\hline Other negatives & 10 & $2 \%$ \\
\hline Past simple tense & 9 & $2 \%$ \\
\hline Future & 9 & $2 \%$ \\
\hline Present continues & 5 & $1 \%$ \\
\hline Passive & 3 & $1 \%$ \\
\hline Present simple question & 2 & $0 \%$ \\
\hline Past simple negative & 2 & $0 \%$ \\
\hline Grand Total & 406 & 1 \\
\hline
\end{tabular}

Figure 4. Errors of prepositions

$\begin{array}{lll}\text { Preposition } & \text { Sum of Ttl } & \text { Sum of } \% \\ \text { to } & 17 & 20 \% \\ \text { for } & 11 & 13 \% \\ \text { in } & 11 & 13 \% \\ \varnothing & 10 & 11 \% \\ \text { on } & 10 & 11 \% \\ \text { of } & 7 & 8 \% \\ \text { at } & 5 & 6 \%\end{array}$




\begin{tabular}{lll} 
with & 5 & $6 \%$ \\
about & 3 & $3 \%$ \\
by & 3 & $3 \%$ \\
from & 2 & $2 \%$ \\
under & 1 & $1 \%$ \\
among & 1 & $1 \%$ \\
while & 1 & $1 \%$ \\
\hline Grand Total & 87 & $100 \%$ \\
\hline
\end{tabular}

\section{Discussion}

A prevalent occurrence of language errors in EFL learners shows that a plethora of studies on causes is slow to show significant changes in its overall goal to improve the present teaching practice. The results of this and other studies confirm three significant points in English language teaching: 1. Studies on error analysis offer a comprehensive, if not exhaustive, tool for narrowing done the list of errors that deserve more attention, 2. there are other factors that influence learning, and 3. errors are inevitable signposts of learning.

Studies have shown that errors are "indicators of progress rather than failure" (Dulay, Burt, \& Krashen, 1982, p. 136) in the learning process. In order to help learners in their progress towards successful learning there are several steps that teachers can follow. Knowing that it is learners who control the classroom input (Corder, 1967; Dulay, Burt, \& Krashen, 1982) and that learning depends on other factors such as environmental elements and personality traits of the learners (Dulay, Burt, \& Krashen, 1982; Corder, 1967; Richards, 1970), teachers can still accomplish their tasks if an extra attention is given to the most frequent errors (Royster, 1913), if there is more contextual and purposeful "input", and if "the idea of individualized approach to language pedagogy" is standardized (Ellis,1989, p.91). On the contrary, learners will make use of other devices to accomplish the given language tasks and end up making errors on the way.

\section{References}

[1] Corder, S.P. (1967, November). The significance of learner's errors. Iral, V(4). 161-169

[2] Corder, S. P. (1981). Error analysis and interlanguage. Oxford: Oxford University Press.

[3] Darus, S., \& Subramaniam, K. (2009). Error analysis of the written English essays of secondary school students in Malaysia: A case study. European Journal of Social Sciences ,8(3), 483-495.

[4] Dulay, H., Burt, M., \& Krashen, S. (1982). Language two. New York: Oxford University Press.

[5] Ellis, R. (1989, November). Second language learning and second language learners: Growth and diversity. TESL Canada Journal/Revue TESL du Canada , 7(1), 74-94.

[6] Earhart, G., \& Small, J. (1915, September). English in the elementary school. The Elementary School Journal, 16(1), 32-48. Retrieved from http://www.jstor.org/stable/994443

[7] Gërmizaj, Sh. (2005). Translation theory in the classroom. Prishtinë.

[8] Gustilo, L., \& Magno, C. (2012, February). Learner's errors and their evaluation: The case of Filipino ESL writers. Philippine ESL Journal, 8, 96-113.

[9] James, C. (1998). Errors in language learning and use: Exploring error analysis. London: Taylor \& Francis.

[10] Kaçani, L. (2013). Probleme të gramatikës në mësimdhënien e mësimnxënien e gjuhës angleze (Unpublished doctoral dissertation). Universiteti i Tiranës, Tiranë. Retrieved from http://www.doktoratura.unitir.edu.al/

[11] Kotsyuk, L. M. (2015). English language error analysis of the written texts produced by Ukrainian learners: Data Collection. Cognitive Studies/Etudes Cognitives, 15, 389-395. 
[12] Nezami, A., \& Najafi, M. S. (2012, March). Common error types of Iranian learners of English. English Language Teaching, 5(3), 160-170.

[13] Novita, R. (2014). An analysis of grammatical errors in the $1^{\text {st }}$ year students' writings at English Department, Andalas University. Vivid Journal, 3(2), 1-15.

[14] Politzer, R.L., \& Ramirez, A.G. (1973, February). An errors analysis of the spoken English of Mexican-American pupils in a bilingual school and a monolingual school. Stanford: Stanford Center for Research and Development in Teaching. Retrieved from https://files.eric.ed.gov/fulltext/ED073879.pdf

[15] Prvulović, M. M. (2014). Analiza grešaka u sastavima na engleskom jeziku. Komunikacija i kultura online, 5(5), 86-101.

[16] Richards, J. C. (1970, March). A non-contrastive approach to error analysis. Paper presented at the TESOL Convention, San Francisco.

[17] Royster, J. F. (1913, October). Common errors in freshman English. The North Carolina High School Bulletin, 4(4), 211-217. Retrieved from http://www.jstor.org/stable/43822084

[18] Saldana, J. (2009). The Coding Manual for Qualitative Researchers. London: Sage Publications Ltd.

[19] Taylor, G. (1986). Errors and explanations. Applied Linguistics, 7(2), 144-165.

[20] Tunaz, M., Muyan, E., \& Muratoğlu, N. (2016). A corpus based study on the preposition error types in Turkish EFL learners essays. UHBAB - Uluslararasi Hakemli Beşeri ve Akademik Bilimler Dergisi/International PeerReviewed Journal of Humanities and Academic Science, 17, 1-16.

[21] Zafar, A. (2016). Error analysis: A tool to improve English skills of undergraduate students. Procedia - Social and Behavioral Sciences, 217, 697-705.

\section{Appendix}

\section{Tables of errors}

Distribution of sentences with errors in Tables 1., 2. and 3. is done based on the correct language structure uses rather than faulty ones because of their convenience and teacher-friendly use.

Table 1. Errors related to prepositions

\begin{tabular}{|c|c|c|c|}
\hline No. & Preposition & Correct Sentences & Sentences with errors \\
\hline \multirow[t]{10}{*}{1.} & $\ln$ & use it in the best way & use it for the best way \\
\hline & & in my opinion & for my opinion \\
\hline & & in my opinion & for my opinion \\
\hline & & in my opinion & for my opinion \\
\hline & & in my thought & for my thought \\
\hline & & $\begin{array}{l}\text { how much of them have success in their } \\
\text { purpose }\end{array}$ & $\begin{array}{l}\text { how much of them have success on their } \\
\text { purpose }\end{array}$ \\
\hline & & to find the best in him & to find the best at him \\
\hline & & find your motivation in it & find your motivation on it \\
\hline & & some believe in a better future & some believe for a better future \\
\hline & & can be useful in keeping in touch with people & $\begin{array}{l}\text { can be useful on keeping in touch with } \\
\text { people }\end{array}$ \\
\hline
\end{tabular}


have doubt in themselves

On

keep on being motivated

play games on our phones

spend time on the phone

we spend a lot time on thing

is spending too much time on social applications

the future depends on us

we are depended on internet

come on time

has a bad influence on us

on the other hand

At

Under

For

To they are staying at home

when my mother wasn't at home

have children[s] at home

at other times

has the right for studying at [the] university;

... put us under [an] unnecessary stress

another reason for students who lack;

use for the purpose of learning

which makes it easier for us

make [it] easier for us

reasons for the lack of knowledge

are the results for [the] lack [of] motivation

are the results of lack motivation... especially for [the] students

they have motivation for this because

a primary reason for [the] lack [of] motivation

things will change for good

another reason for me is

they are going to the

to go to faculty

if you go to any restaurant

since they start going to high school have doubt on themselves

keep being motivated

play games in our phones

spend time in the phone

we spend a lot time in thing

is spending too much time in social applications

the future depends to us

we are depended from internet

come at time

has a bad influence to us

in the other hand

they are staying in home

when my mother wasn't in home

have childrens in home

in the other times

has the right for studying in university;

who put us in unnecessary stress

another reason of students who lack;

use in purpose to learn

which makes to us easier

make to us more easier

reasons of the lack of knowledge

are the results of lack motivation

are the results of lack motivation... especially at students

they have motivation in this because

a primary reason of lack motivation

things will change in good

another reason to me is

they are going at the

to go in faculty

if you go in any restaurant

since they start going on high school 
someone don't have money to go to other state

the key to success at learning process

solution to the problem

listen to music

to listen to a teacher

I'm listening to professor

addicted to technology

addicted to technology

to adapt to the system

that will come to the Upz at the future

which students came to university

they are always saying to me

he said to me you have

$\varnothing$

With

Of many people

I went home

we shall build [a] future

prices of students can be many kinds

I didn't find it myself yet

they give up all the habits

will help students find

because we need this

nowadays

it will not only benefit us having a strong

maybe the[re is a] problem with us

starting with myself

this problem stands with the students that are

every student feels comfortable with

if teachers..give..help with their decisions

are the results [for the] lack of motivation

a primary reason of [the] lack of motivation

most of reasons

most of [the] students someone don't have money to go in other state

the key of success at learning process

solution of the problem

listen music;

to listen a teacher

I'm listening professor

addicted from technology

addicted on technology

to adapt with the system

that will come at the Upz at the future

which students came in university

they are always saying me

he said me you have

many of people;

I went to the home

we shall build of future

prices of students can be of many kinds

I didn't find it for myself yet

they give up from all the habits

will help students to find

because we need for this

in nowadays

it will not only benefit with us having a strong

maybe the problem is to us

starting by myself

this problem stands at the students that are

every student feels comfortable on

if teachers ..give..help on their decisions

are the results of lack motivation

a primary reason of lack motivation

most reasons

the most students 
this is one of reasons

the most important part of learning for a student

to increase motivations of students

By

While

About

From

Among their thoughts are accepted by the teacher

to be accepted by [the] university

without their families and to be missed by them

and enjoy while it lasts

they do not think a lot about studying

talking about the internet

they think about the present

if we look from one side

if I could stay far from my family

among students of universities this is one for reasons

the most important part on learning for a student

to increase motivations at students

their thoughts are accepted to the teacher

to be accepted on university

without their families and to be missed for them

and enjoy as it lasts

they do not think a lot for studying

talking for the internet

they think for the present

if we look at one side

if I could stay far from my family

in students of universities

Table 2. Errors related to present simple tense of verbs

\begin{tabular}{|c|c|c|}
\hline Present simple affirmative & All the errors & \\
\hline & our family spend money & if a student feel good \\
\hline & nobody notice you & we don't have anyone to ask...so we failed sometimes \\
\hline & some students is have & teacher appreciate them \\
\hline & the situation are & Kosova have a lot of \\
\hline & all of us knows & I'm agree with \\
\hline & some students likes & teachers needs to \\
\hline & students who studies & one of the students who study here \\
\hline & the student have to like & as a quote say... \\
\hline & even they "graduted" & university studies seems to be \\
\hline & $\begin{array}{l}\text { students leave the city... and } \\
\text { going to another one }\end{array}$ & using to much social..they lost a lot of time \\
\hline & everyone have & everybody dream \\
\hline & our teacher tell to us & every student have a plan \\
\hline & somebody ask & a student sacrifice all his life \\
\hline & everybody have reasons & students needs better \\
\hline & $\begin{array}{l}\text { if I finish university and I } \\
\text { couldn't find a job }\end{array}$ & a lot of students wants \\
\hline & $\begin{array}{l}\text { one student need to be a } \\
\text { good person }\end{array}$ & not reading enough books have it's own reason \\
\hline & $\begin{array}{l}\text { help others who needs your } \\
\text { help }\end{array}$ & information that ...help us \\
\hline & teacher which explain & my friends works in a different jobs \\
\hline & $\begin{array}{l}\text { this strategy increase my } \\
\text { motivation }\end{array}$ & smartphones and technology ..is the main reason \\
\hline & $\begin{array}{l}\text { not just to hear the lessons } \\
\text { that teachers says }\end{array}$ & students who works \\
\hline & people who wants to be & if anyone have their reasons \\
\hline & every students have & that this mean everything ...the student are not \\
\hline & $\begin{array}{l}\text { maybe this help and } \\
\text { motivate us }\end{array}$ & a student that ... want to graduate \\
\hline
\end{tabular}




\begin{tabular}{|l|l|l|} 
& $\begin{array}{l}\text { a lot of professors that } \\
\text { teach's us }\end{array}$ & after they are getting graduated ....won't stay \\
\hline & are my parent & if the teacher use \\
\hline & he/she have attitude & everyone choose the university \\
\hline & they comes in university & student's goes to the pub \\
\hline & if my parents want's & question that have more of one answers \\
\hline & teacher use sentences & students that studies \\
\hline & every person have & when someone ask me \\
\hline & the students thinks & since we born \\
\hline & everyone need a strategy & money make you important \\
\hline & our country need to changes & respecting people make you \\
\hline present simple negative & students doesn't spent & student's ......doesn't have; \\
\hline & about those who doesn't & they don't thinking \\
\hline & students haven't motivation & most of students doesn't have... \\
\hline & this dosen't happen & because they are no motivation; \\
\hline & $\begin{array}{l}\text { someone don't have money } \\
\text { to go in other state }\end{array}$ & and not have much time \\
\hline & $\begin{array}{l}\text { teachers are great, } \\
\text { but...some of them no }\end{array}$ & why people don't learning \\
\hline & $\begin{array}{l}\text { people who doesn't finished } \\
\text { their school }\end{array}$ & why studen't doesn't learn \\
\hline & $\begin{array}{l}\text { student's not have any } \\
\text { reason }\end{array}$ & they...because not have any free \\
\hline present simple question & why you say that? & you know why \\
\hline & \multicolumn{2}{|l}{} \\
\hline
\end{tabular}

Table 3. Singular/Plural Forms

\begin{tabular}{|c|c|}
\hline Singular/plural & six professor \\
\hline \multirow[t]{18}{*}{ Irregular and no plural } & four hour in day \\
\hline & my parents are professor \\
\hline & give motivation to student \\
\hline & peoples \\
\hline & peoples \\
\hline & peoples \\
\hline & other peoples \\
\hline & childrens \\
\hline & have childrens in home \\
\hline & lifes \\
\hline & lifes \\
\hline & achieve anything in our lifes \\
\hline & to continue their lifes \\
\hline & we have to... for ourself \\
\hline & make a class to have motive to do.. \\
\hline & one old men \\
\hline & knowledges, \\
\hline & presences, \\
\hline \multirow[t]{4}{*}{ Other/another } & give them other example of people \\
\hline & there are other reason \\
\hline & in other university \\
\hline & another reasons \\
\hline this/these & from this things \\
\hline
\end{tabular}




\begin{tabular}{|c|c|}
\hline & if students have all this things \\
\hline \multirow[t]{5}{*}{ One of the } & it's one of the reason \\
\hline & one of the reason \\
\hline & one of the reason \\
\hline & one of the reason \\
\hline & one of the main problem \\
\hline \multirow[t]{3}{*}{ some/any + plural noun } & this are some of the reasons \\
\hline & some of the professor don't do that \\
\hline & don't have any job \\
\hline \multirow[t]{5}{*}{ much/many } & I have much options \\
\hline & there are so much reasons \\
\hline & how much of them (students) have \\
\hline & most student have \\
\hline & many of student in the world \\
\hline \multirow[t]{4}{*}{ a few/ a lot } & those are a few reason \\
\hline & in a lot of university \\
\hline & a lot of reason \\
\hline & there are lots of reason \\
\hline \multirow[t]{4}{*}{ every } & not every parents are \\
\hline & in every lessons in school \\
\hline & for every parents \\
\hline & in every bad circumstances \\
\hline \multirow{5}{*}{ Singular form } & using a smart phones \\
\hline & a successful students is \\
\hline & a students knowledge \\
\hline & in a different jobs \\
\hline & have educations \\
\hline \multirow[t]{17}{*}{ plural form } & from students' \\
\hline & a students' life \\
\hline & student's must \\
\hline & thing's changed \\
\hline & thing's be better \\
\hline & the number of student's \\
\hline & all student's need \\
\hline & use ..phones' inside of books' \\
\hline & student's are not motivated \\
\hline & students' \\
\hline & read books' \\
\hline & parent's \\
\hline & like student's we are \\
\hline & student's are \\
\hline & some student's which \\
\hline & better university's \\
\hline & some students' \\
\hline
\end{tabular}

